\title{
22. HIGH-MOLECULAR-WEIGHT HYDROCARBONS IN A SOUTH LATITUDE SETTING OFF THE COAST OF CHILE, SITE 859'
}

\author{
Keith A. Kvenvolden, ${ }^{2}$ Jürgen Rullkötter, ${ }^{3}$ Frances D. Hostettler, ${ }^{2}$ John B. Rapp, ${ }^{2}$ Ralf Littke, ${ }^{4}$ \\ Ulrich Disko, ${ }^{4}$ and Barbara Scholz-Böttcher ${ }^{3}$
}

\begin{abstract}
High-molecular-weight aliphatic (non-aromatic) hydrocarbons were extracted from seven late Pliocene and one late Pleistocene sediment samples obtained by drilling at Ocean Drilling Program (ODP) Site 859 holes in mainly terrigenous clastic sediment of a small accretionary wedge near the toe of the lower slope of the Chile Trench. This site is located about $18 \mathrm{~km}$ north of the Chile Triple Junction, a tectonically active area with hydrothermal fluid activity associated with a subducting spreading ridge. The samples investigated contain variable mixtures of indigenous hydrocarbons, typical of a very early stage of diagenesis, and of migrated hydrocarbons that have encountered high thermal stress. Indigenous hydrocarbons are of a mixed terrigenous and marine origin. The high geothermal gradient at Site $859\left(\sim 100^{\circ} \mathrm{C} / \mathrm{km}\right)$ and the hot fluids in the deep subsurface have not significantly affected the hydrocarbons in the drilled sediment section down to a subbottom depth of about $450 \mathrm{~m}$. Our results suggest that the present geothermal conditions at Site 859 have not been maintained in the past for sustained periods of time.
\end{abstract}

\section{INTRODUCTION}

Southern high latitudes $\left(>45^{\circ} \mathrm{S}\right)$ encompass the southern oceans, the continent of Antarctica, and the southern end of South America (Fig. 1). In this vast region, which is dominated by the southern oceans, organic geochemical studies of high-molecular-weight hydrocarbons in oceanic sediment have been minimal, with most attention being directed to sediment lying off the coast of Antarctica. For example, in 1984 a marine geological and geophysical investigation was undertaken off the coast of Wilkes Land and in the Ross Sea (Eittreim, Cooper, and Scientific Staff, 1984). Sediment samples from this investigation have been studied, and the hydrocarbon geochemistry has been described (Kvenvolden, Golan-Bac, Rapp, 1987; Kvenvolden, Rapp, et al., 1987; Rapp et al., 1987). These studies concluded that hydrocarbons came from both marine and terrigenous sources and that the terrigenous component probably represents recycled sediment. Later Venkatesan (1988) described the lipid geochemistry of some sediment samples collected in 1983, and she also concluded that the organic matter is mainly recycled and mixed with some modern marine material. In other related studies of Ross Sea sediment, McIver (1975) analyzed hydrocarbon gases from Deep Sea Drilling Project (DSDP) sites, Sackett et al. (1974) first recognized the importance of organic matter recycling in Antarctic sediment, and Matsumoto, Torii, and Hanya (1979) studied a dump site at McMurdo Station.

Organic geochemical studies of sediment samples from the area of the Bransfield Strait (Fig. 1) have indicated that thermogenic hydrocarbons are present locally (Whiticar et al., 1985; Brault and Simoneit, 1988), and that both marine and lesser amounts of recycled terrigenous hydrocarbons are dispersed in the sediment (Venkatesan and Kaplan, 1987). In sediment of the nearby Weddell Sea (Fig. 1), hydrocarbons in Cretaceous sediment appear to be mainly primary (first cycle), whereas the hydrocarbons in Tertiary sediment are probably recycled (Kvenvolden et al., 1990). Aliphatic hydrocarbons in Prydz Bay (Fig. 1) sediments contrast with those elsewhere off the coast of Antarctica

\footnotetext{
'Lewis, S.D., Behrmann, J.H., Musgrave, R.J., and Cande, S.C. (Eds.), 1995. Proc. $O D P_{2}$ Sci. Results, 141: College Station, TX (Ocean Drilling Program).

U.S. Geological Survey, 345 Middlefield Road, MS 999, Menlo Park, CA 94025.

${ }^{3}$ Institut für Chemie und Biologie des Meeres (ICBM), Carl von Osseitzky Universität Oldenburg, D-26111 Oldenburg, Federal Republic of Germany.

${ }^{4}$ Institut für Erdöl und Organische Geochemie (ICG-4), Forschungszentrum Jülich $\mathrm{GmbH}(\mathrm{KFA})$, D-52425 Jülich, Federal Republic of Germany.
} U.S.A. in being dominated by terrigenous components of intermediate organic maturity (Kvenvolden et al., 1991). For the subantarctic region, Mackie, Platt, and Hardy (1978) described hydrocarbons in sediment from King Edward Cove on the island of South Georgia (Fig. 1), and Simoneit (1980) and von der Dick, Rullkötter, and Welte (1983) discussed the organic geochemistry of sediment from two DSDP sites cored near the Falkland Plateau (Fig. 1).

These organic geochemical studies from antarctic and subantarctic regions form the background for our investigation of hydrocarbons in sediment at Ocean Drilling Program (ODP) Site 859 off the coast of southern Chile. Site 859 lies on a transect (Seismic Line 745) along the northern end of the subducting ridge segment $18 \mathrm{~km}$ north of the present-day Chile Triple Junction (Bangs et al., 1992). Seven late Pliocene and one late Pleistocene silty clay to clayey silt samples, ranging in subbottom depth from 440.4 to 4.8 mbsf, were collected by coring at Site 859 in sediment covering a small accretionary wedge near the toe of the continental slope close to the Chile Trench. Total depth of Borehole $859 \mathrm{~B}$ was $476.1 \mathrm{mbsf}$. These eight samples were studied in two different laboratories, and the results provide a rather limited data base from which to try to understand the hydrocarbon geochemistry of this offshore sediment record.

\section{EXPERIMENTAL METHODS}

The geochemical procedures that were used for four of the samples (second through fifth samples in Table 1) is the same as described previously for studies of sediment from the Weddell Sea (Kvenvolden et al., 1990) and from Prydz Bay (Kvenvolden et al., 1991). The sediment samples, collected aboard JOIDES Resolution, had been carefully wrapped in cleaned aluminum foil and frozen immediately in sealed plastic bags for storage. For analysis, water was removed by air drying; then the dried samples were pulverized and sieved through a 32 mesh screen. For extraction and identification of hydrocarbons, we used from 51 to $83 \mathrm{~g}$ of pulverized and sieved sediment. Each sample was triple extracted with dichloromethane by shaking on a wrist-action shaker. The combined filtered extracts were concentrated by turbo evaporation. Any sulfur was removed by filtration through activated copper. The dichloromethane solvent was then exchanged for hexane.

The extracts in hexane were fractionated by liquid-solid chromatography using a column packed with activated silica gel and partially deactivated alumina. The column was sequentially eluted with hexane, 
Table 1. Organic geochemical parameters in sediment samples from Leg 141, Site 859.

\begin{tabular}{|c|c|c|c|c|c|c|c|c|c|c|c|c|c|}
\hline $\begin{array}{l}\text { Core, section, } \\
\text { interval }(\mathrm{cm})\end{array}$ & $\begin{array}{l}\text { Depth } \\
\text { (mbsf) }\end{array}$ & Age & $\begin{array}{l}\mathrm{OC} \\
(\%)\end{array}$ & $\mathrm{CPI}_{13-21}$ & $\mathrm{CPI}_{23-33}$ & $\frac{C_{16}}{C_{31}}$ & $\frac{\mathrm{Pr}}{\mathrm{Ph}}$ & $\frac{\mathrm{Pr}}{\mathrm{C}_{17}}$ & $\frac{\mathrm{Ph}}{\mathrm{C}_{18}}$ & $\begin{array}{l}\text { Hopene } \\
\text { Hopane }\end{array}$ & $\begin{array}{c}\mathrm{C}_{31} \\
22 S /(S+R)\end{array}$ & $\begin{array}{c}\mathrm{C}_{32}-\mathrm{C}_{35} \\
22 S /(S+R)\end{array}$ & $\begin{array}{c}\mathrm{C}_{29} \\
20 S /(S+R)\end{array}$ \\
\hline $\begin{array}{l}141-859 \mathrm{~A}- \\
2 \mathrm{H}-3,60-66\end{array}$ & 4.8 & 1. Pleistocene & 1.1 & 1.09 & 4.02 & 0.15 & 1.15 & 0.61 & 0.59 & 0.0 & 0.09 & 0.61 & 0.41 \\
\hline $\begin{array}{l}141-859 \mathrm{~B} \\
4 \mathrm{R}-2,15-20 \\
10 \mathrm{R}-2,139-145 \\
12 \mathrm{R}-2,40-46 \\
15 \mathrm{R}-1,104-110 \\
29 \mathrm{R}-3,45-51 \\
32 \mathrm{R}-1,77-83 \\
35 \mathrm{R}-2,120-126\end{array}$ & $\begin{array}{l}141.6 \\
198.4 \\
217.6 \\
246.1 \\
382.9 \\
409.4 \\
440.4\end{array}$ & $\begin{array}{l}\text { 1. Pliocene } \\
\text { 1. Pliocene } \\
\text { I. Pliocene } \\
\text { I. Pliocene } \\
\text { 1. Pliocene } \\
\text { 1. Pliocene } \\
\text { 1. Pliocene }\end{array}$ & $\begin{array}{l}0.3 \\
0.3 \\
0.1 \\
0.4 \\
0.3 \\
0.2 \\
0.3\end{array}$ & $\begin{array}{l}0.99 \\
1.07 \\
1.09 \\
1.06 \\
0.86 \\
0.89 \\
1.14 \text { ? }\end{array}$ & $\begin{array}{l}5.14 \\
6.85 \\
5.16 \\
6.12 \\
3.72 \\
1.94 \\
1.82 ?\end{array}$ & $\begin{array}{l}3.08 \\
1.19 \\
3.68 \\
1.07 \\
0.98 \\
1.04 \\
0.11 ?\end{array}$ & $\begin{array}{l}1.61 \\
1.46 \\
1.34 \\
1.32 \\
0.66 \\
0.48 \\
\text { ND }\end{array}$ & $\begin{array}{l}0.38 \\
0.38 \\
0.32 \\
0.36 \\
0.61 \\
0.91 \\
\text { ND }\end{array}$ & $\begin{array}{l}0.40 \\
0.44 \\
0.38 \\
0.49 \\
1.37 \\
2.46 \\
\mathrm{ND}\end{array}$ & $\begin{array}{l}1.7 \\
0.9 \\
4.0 \\
3.4 \\
3.1 \\
0.6 \\
\text { ND }\end{array}$ & $\begin{array}{l}0.1 \\
0.1 \\
0.02 \\
0.02 \\
0.06 \\
0.51 \\
0.34\end{array}$ & $\begin{array}{l}\text { ND } \\
\text { ND } \\
\text { ND } \\
\text { ND } \\
0.56 \\
0.56 \\
0.65\end{array}$ & $\begin{array}{l}\text { ND } \\
\text { ND } \\
\text { ND } \\
\text { ND } \\
0.05 \\
0.21 \\
\text { ND }\end{array}$ \\
\hline
\end{tabular}

Notes: $\mathrm{OC}=$ organic carbon; $\mathrm{CPI}_{13-21}, 1 / 21\left(n-\mathrm{C}_{13}+n-\mathrm{C}_{15}+n-\mathrm{C}_{17}+n-\mathrm{C}_{19}+n-\mathrm{C}_{21}\right) /\left(n-\mathrm{C}_{12}+n-\mathrm{C}_{14}+n-\mathrm{C}_{16}+n-\mathrm{C}_{18}+n-\mathrm{C}_{20}\right)+\left(n-\mathrm{C}_{13}+n-\mathrm{C}_{15}+n-\mathrm{C}_{17}+n-\mathrm{C}_{19}+n-\mathrm{C}_{21}\right) /\left(n-\mathrm{C}_{14}+n-\right.$ $\left.\left.\mathrm{C}_{16}+n-\mathrm{C}_{18}+n-\mathrm{C}_{20}+n-\mathrm{C}_{22}\right)\right] ; \mathrm{CPI}_{23-33}, \mathrm{I} / 2\left[\left(n-\mathrm{C}_{23}+n-\mathrm{C}_{25}+n-\mathrm{C}_{27}+n-\mathrm{C}_{29}+n-\mathrm{C}_{31}+n-\mathrm{C}_{33}\right) /\left(n-\mathrm{C}_{22}+n-\mathrm{C}_{24}+n-\mathrm{C}_{26}+n-\mathrm{C}_{28}+n-\mathrm{C}_{30}+n-\mathrm{C}_{32}\right)+\left(n-\mathrm{C}_{23}+n-\mathrm{C}_{25}+n-\mathrm{C}_{27}+n-\right.\right.$ $\left.\left.\mathrm{C}_{29}+n-\mathrm{C}_{31}+n-\mathrm{C}_{33}\right) /\left(n-\mathrm{C}_{24}+n-\mathrm{C}_{26}+n-\mathrm{C}_{28}+n-\mathrm{C}_{30}+n-\mathrm{C}_{32}+n-\mathrm{C}_{34}\right)\right] ; \mathrm{C}_{16} / \mathrm{C}_{31}, n-\mathrm{C}_{16} / n-\mathrm{C}_{31} ; \mathrm{Pr} / \mathrm{Ph}$, pristane $(2,6,10,14-$ tetramethylpentadecane $) /$ phytane $(2,6,10,14-t e t r a m e-$

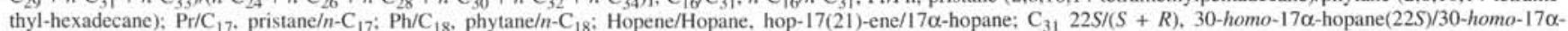
hopane $(22 S)+(22 R) ; \mathrm{C}_{32}-\mathrm{C}_{35} 22 S /(S+R)$, average of $22 S /(S+R)$ for 30-dihomo-17 $\alpha$-hopane +30 -trihomo-17 $\alpha$-hopane +30 -tetrakishomo-17 $\alpha$-hopane +30 -pentakishomo-17 $\alpha$ hopane: $\mathrm{C}_{29} 20 S /(S+R), 24$-ethyl-5 $\alpha$-cholestane $(20 S) / 24$-ethyl- $5 \alpha$-cholestane $(20 S)+(20 R) ; \mathrm{ND}=$ not determined.

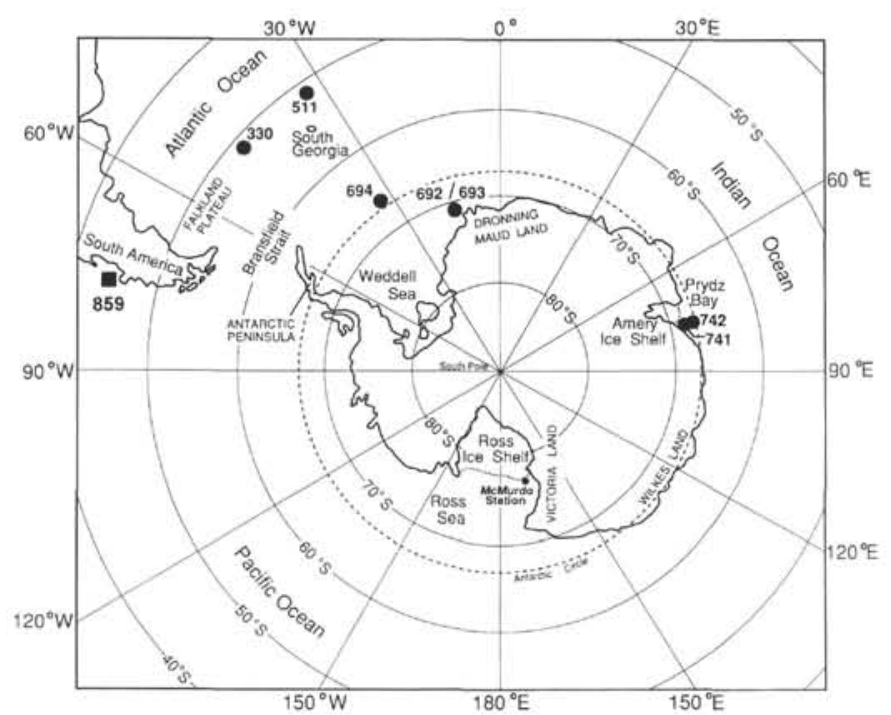

Figure 1. Map of the southern oceans showing geographic features and some Ocean Drilling Program sites where relevant organic geochemical studies have been conducted. Leg 141 Site 859 (this study) is located off the coast of South America in the Pacific Ocean. Also shown are ODP Sites 692, 693, and 694 in the Weddell Sea and Sites 741 and 742 in Prydz Bay; DSDP Sites 330 and 511 are located in the Atlantic Ocean northeast of the Bransfield Strait and east of the Falkland Plateau.

$20 \%$ benzene in hexane, benzene, and methanol. Only the first fraction, containing mainly aliphatic hydrocarbons, was studied in detail by high-resolution gas chromatography, using a $30-\mathrm{m}$ by $0.3-\mathrm{mm}$ fusedsilica column coated with DB-1 bonded-phase. Identification of $n$ alkanes, and isoprenoid hydrocarbons (pristane and phytane), was based on retention times and comparison with standards. Relative proportions of the individual compounds were determined from integrator peak heights. Portions of the first fractions were examined by gas chromatography-mass spectrometry (GC-MS) using a 30 -m by $0.3-$ $\mathrm{mm}$ fused-silica column coated with DB- 5 bonded phase. Multipleion detection (MID) of $\mathrm{m} / \mathrm{z}, 191,215,217,231,243$, and 257 produced mass chromatograms from which terpanes, steranes/diasteranes, fernenes, and diasterenes were identified based on their key fragments and relative retention times.

The four remaining samples (first and last three samples in Table 1), after drying at ambient temperature, were extracted using a modified flow-blending technique (Radke et al., 1978) with dichloro-
methane/I\% methanol as the solvent. Extracts were separated into compound classes by medium pressure liquid chromatography (Radke et al., 1980). Non-aromatic hydrocarbon fractions were analyzed by gas chromatography on a $25-\mathrm{m}$ by $0.32-\mathrm{mm}$ fused-silica capillary column coated with cross-linked SE-54 polysiloxane. GCMS was done using a $50-\mathrm{m}$ by $0.32-\mathrm{mm}$ capillary column coated with DB-5 bonded phase. Compound identification from the full scan mode used a scan rate of about $1.5 \mathrm{~s} / \mathrm{scan}$ over the appropriate mass range. Calculation of hopane and sterane compound ratios is based on $\mathrm{B}^{2} / \mathrm{E}$ linked scan measurements that were performed for selected molecular-ion, key-fragment transitions $\left(\mathrm{M}^{+} \rightarrow m / z, 191\right.$ for hopanes and $\mathrm{M}^{+} \rightarrow m / z 217$ or 218 for steranes).

\section{RESULTS}

Non-aromatic hydrocarbon distributions for seven of the samples analyzed are shown in Figure 2. The gas chromatogram of the nonaromatic hydrocarbon fraction of the deepest sample from $440.4 \mathrm{mbsf}$ is not shown because the distribution is strongly obscured by a number of contaminant peaks of unknown identity and origin. Except for the shallowest and the deepest sample, the $n$-alkane distributions are bimodal, and the chromatograms exhibit a pronounced envelope of unresolved components around $n$-octadecane $\left(C_{18}\right)$. To facilitate comparison of the gas chromatographic distributions of the different nonaromatic hydrocarbon fractions, a number of molecular compound ratios were calculated (Table 1). The relative proportions of $n$-alkanes are described by Carbon Preference Indices (CPI) calculated over two different molecular weight ranges $\left(C_{13}\right.$ to $C_{21}$ and $C_{23}$ to $\left.C_{33}\right)$ following the method of Cooper and Bray (1963).

The relative proportions of the two $n$-alkane distribution modes are expressed by the ratios of $n-\mathrm{C}_{16}$ to $n-\mathrm{C}_{31}\left(\mathrm{C}_{16} / \mathrm{C}_{31}\right)$. The values of this ratio in Samples 141-859A-2H-3, 60-66 cm (4.8 mbsf), and 141-859B-35R-2, 120-126 cm (440.4 mbsf), are 0.15 and 0.11 , respectively, indicating a single mode in the higher molecular weight range. The values of this ratio for the other six samples range from 0.98 to 3.68 and either show two modes of about equal proportions or show the lower molecular weight dominating the higher molecular weight mode (Table 1 and Fig. 2).

The values of $\mathrm{CPI}_{13-21}$ range from 0.86 to 1.14 with most values between 0.99 and 1.09 , a distribution that indicates that odd- and even-carbon-numbered $n$-alkanes are equally abundant in the carbon number range between $n-\mathrm{C}_{13}$ and $n-\mathrm{C}_{21}$. The $\mathrm{CPI}_{13-21}$ values of 0.86 and 0.89 (Table 1) for Samples 141-859B-29R-3, 45-51 cm (382.9 mbsf), and 141-859B-32R-1, 77-83 cm (409.4 mbsf), suggest that even-carbon-numbered $n$-alkanes dominate slightly in this molecular weight range. However, inspection of the gas chromatograms (Fig. 2) shows that these two low values result mainly from the lower relative 


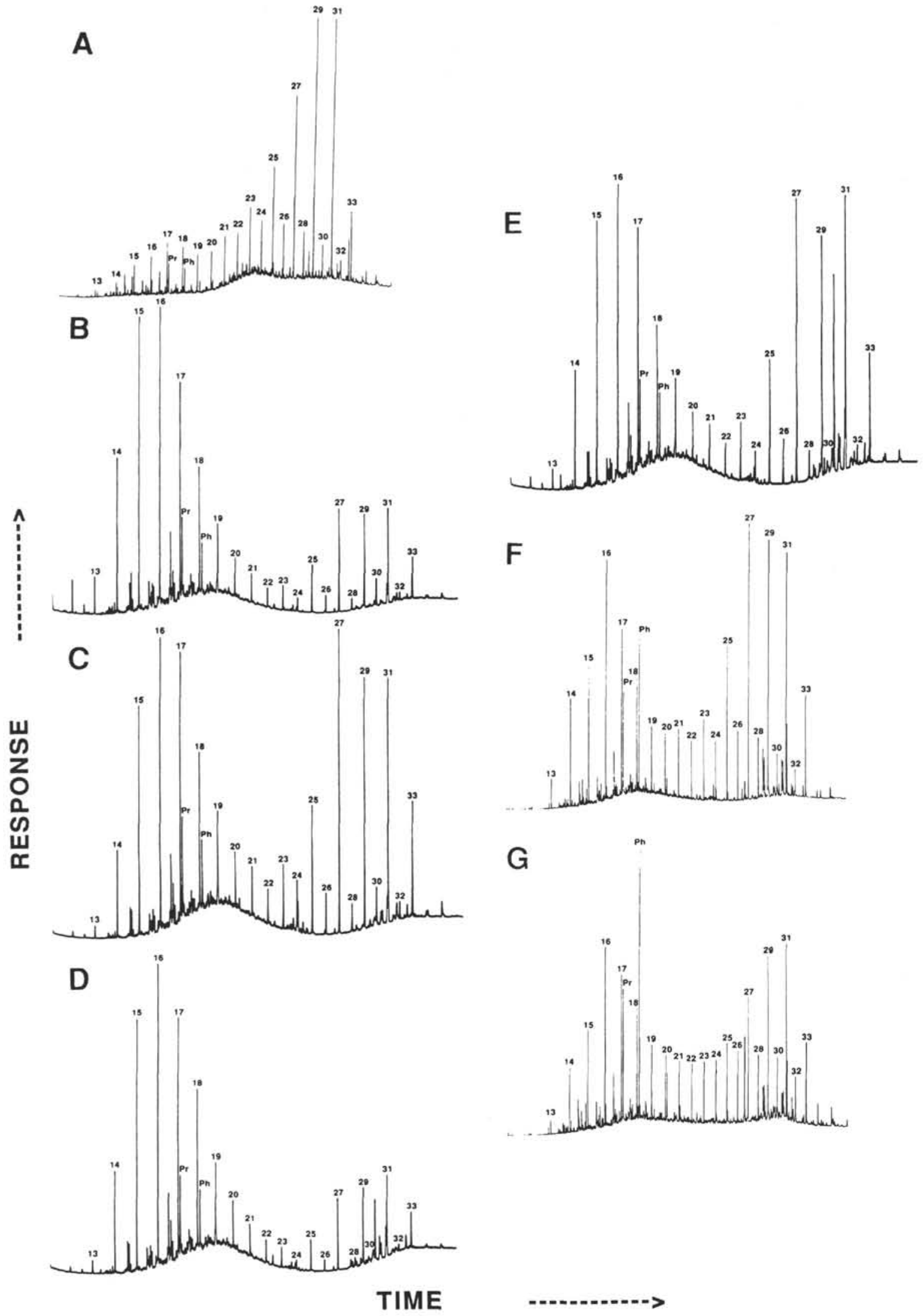

Figure 2. Gas chromatograms of the non-aromatic hydrocarbon fractions of extractable bitumen of seven ODP Site 859 sediments. A. 141-859A-2H-3, 60-66 cm (4.8 mbsf). B. 141-859B-4R-2, 15-20 cm (141.6 mbsf). C. 141-859B-10R-2, 139-145 cm (198.4 mbsf). D. 141-859B-12R-2, 40-46 cm (217.6 mbsf). E. 141-859B-15R-1, 104-110 cm (246.1 mbsf). F. 141-859B-29R-3, 45-51 cm (382.9 mbsf). G. 141-859B-32R-1, 77-83 cm (409.4 mbsf). On the gas chromatograms shown, the $n$-alkanes are identified by their carbon number and the isoprenoids by $\mathrm{Pr}$ for pristane and $\mathrm{Ph}$ for phytane. 
abundance of $n-\mathrm{C}_{15}$ that may have been affected (partly lost) by solvent evaporation. In contrast, in the higher molecular weight range the values of $\mathrm{CPI}_{23-33}$ are large, ranging from 1.82 to 6.85 , resulting from a strong dominance of the odd-carbon-numbered $n$-alkanes.

The distribution of the isoprenoid hydrocarbons are defined by the pristane/phytane $(\mathrm{Pr} / \mathrm{Ph})$ ratios, and the proportion of these compounds to the $n$-alkanes are given by the pristane/ $n-\mathrm{C}_{17}\left(\mathrm{Pr} / \mathrm{C}_{17}\right)$ and phytane $/ n-\mathrm{C}_{18}\left(\mathrm{Ph} / \mathrm{C}_{18}\right)$ ratios (Table 1$)$. In the five most shallow samples studied ( 4.8 to $246.1 \mathrm{mbsf}$ ) pristane is more abundant than phytane, but toward the bottom of the hole ( 382.9 to $409.4 \mathrm{mbsf}$ ) the relative abundances of these two isoprenoids reverse. Values of the $\mathrm{Pr} / \mathrm{C}_{17}$ ratios show that the $n$-alkane is always more abundant than the isoprenoid. $\mathrm{Ph} / \mathrm{C}_{18}$ ratios are less than unity in the five most shallow samples, but the isoprenoid is more abundant than the accompanying $n$-alkane in the deeper samples. Pristane and phytane cannot be distinguished in the deepest sample ( $440.4 \mathrm{mbsf}$ ) because of obscuring contaminants.

Polycyclic non-aromatic hydrocarbons consist predominantly of hopanoids of bacterial origin (Ourisson et al., 1979). The distributions of saturated hopanes and unsaturated hopenes are shown in Figure 3 based on the $m / z 191$ mass chromatograms for five selected samples; compounds identified are listed in Table 2. The $\mathrm{m} / \mathrm{z}, 243$ mass chromatograms characteristic of fernenes are also shown in Figure 3. Fernenes are also assumed to be of bacterial origin (Brassell et al., 1981). Whereas there is a systematic depth trend for the distribution of the fernene double-bond isomers, which can be explained in terms of progressing diagenesis, variation in the relative abundances of hopenes and hopanes and of hopane stereoisomers is less regular as a function of depth (Table 1).

Steroid hydrocarbons are less prominent in the sediments from ODP Site 859 . Three typical examples of their distribution are given in Figure 4, based on mass chromatograms of $m / z 215$ (sterenes), 217 (steranes), and 257 (sterenes and diasterenes). The sterene distribution is comprised of the diagenetically least stable $\Delta^{2}$-isomers down to the deepest sample studied at $409.4 \mathrm{mbsf}$. The sterane pattern (Fig. $4 \mathrm{~A})$ is the most complex in Sample 141-859A-2H-3, 60-66 cm (4.8 mbsf). This complexity is also evident in the summed molecular ion-to- $m / z 217$ transitions from the linked scan experiments, which selectively monitor steranes and avoid any contributions from sterenes and other components (Fig. 5). With the decrease in the complexity of the sterane patterns with depth there is an increase in the apparent thermal maturity based on sterane molecular maturation parameters (e.g., the ratio of the thermogenic $20 S$ epimer of 24-ethylcholestane relative to the sum of the $20 S$ plus the biogenic and less stable $20 R$ epimer; $\mathrm{C}_{29} 20 S /[S+R]$ in Table 1). In all samples, except Sample 141-859B-29R-3, 45-51 cm (Fig. 4B), diasterenes are subordinate to regular sterenes.

\section{DISCUSSION}

The values of the organic geochemical parameters measured on sediment from ODP Site 859 are unusual compared to those of other sediments from the southern oceans, particularly the sediments closer to Antarctica (Fig. 1). Organic carbon values for late Pliocene sediment at Site 859 are low, less than $0.5 \%$ (Table 1). Only Sample 141-859A-2H-3, 60-66 cm, of late Pleistocene age has an organic carbon value exceeding $1 \%$. Thus, most of the sediments at Site 859 are organic-matter-lean, which is a characteristic also of Cenozoic samples from the Weddell Sea, Antarctica (Kvenvolden et al., 1990) but not of the Cenozoic sediments from Prydz Bay, Antarctica (Kvenvolden et al., 1991).

The bimodal $n$-alkane distributions in sediments at Site 859 (Fig. 2) suggest two sources for these compounds. The higher-molecularweight mode with its strong odd-carbon-numbered dominance likely represents contributions of waxes from vascular plants of terrigenous (continental) origin (Eglinton et al., 1962). Similar observations and interpretations have been made from marine sediments worldwide
(Simoneit, 1978). The unique aspect of these $n$-alkanes at Site 859 is the magnitude of the odd-carbon-numbered dominance that has a remarkable maximum $\mathrm{CPI}_{23-33}$ of 6.85 in Sample 141-859B-10R-2, $139-145 \mathrm{~cm}$ (198.4 mbsf). The $\mathrm{CPI}_{23-33}$ values are lower at depththat is, 1.94 for Sample 141-859B-32R-1, 77-83 cm (409.4 mbsf), and 1.82 for Sample 141-859B-35R-2, 120-126 cm (440.4 mbsf)-likely reflecting diagenetic formation of $n$-alkanes from polar precursors with a less pronounced odd-carbon-number predominance. At Site 859 the higher-molecular-weight $n$-alkanes were probably derived from plants, are primary (not recycled) and were transported from the South American continent. In contrast, higher-molecular-weight $n$-alkanes found offshore of Antarctica are likely recycled plant material transported from the Antarctic continent at an earlier geologic time when plant life was abundant there (Kvenvolden et al., 1990).

In the lower-molecular-weight distribution mode, odd- and evencarbon-numbered $n$-alkanes are almost evenly distributed in each sediment sample from Site 859 (Fig. 2). Although lower molecular weight $n$-alkanes have been invoked to represent primary planktonic sources (Clark and Blumer, 1967; Han and Calvin, 1969; Simoneit, 1978 ), in this case these compounds are likely to be mainly hydrocarbons generated under higher thermal stress. They were introduced into these sediments as part of more mature recycled (eroded) organic matter or by redistribution (migration) within the sedimentary column from a deeper section. It is unlikely that a large proportion of these lower-molecular-weight $n$-alkanes are of primary origin in this oxic depositional environment of low organic carbon content.

$\mathrm{Pr} / \mathrm{Ph}$ ratios have been used to assess paleoenvironments (Didyk et al., 1978), although it has been shown later that the ratio has restricted use (ten Haven et al., 1987). Under anoxic conditions $\mathrm{Pr} / \mathrm{Ph}$ ratios much less than 1.0 would be expected if the general model of Didyk et al. (1978) is accepted. At Site $859 \mathrm{Pr} / \mathrm{Ph}$ ratios in the five most shallow samples studied range from 1.15 to 1.61 (Table 1), and these values are interpreted to represent an oxic environment of deposition at this site. $\mathrm{Pr} / \mathrm{Ph}$ ratios in the two samples from 382.9 and 409.4 mbsf are less than unity; the higher-molecular-weight $n$ alkanes in these two samples were likely affected by increasing diagenesis, as is phytane that increases in concentration relative to pristane and $n-C_{18}$. It is possible that phytane was diagenetically formed in a reducing sedimentary microenvironment from polar precursors of planktonic and/or bacterial origin.

The polycyclic non-aromatic hydrocarbons are the most important class of the so-called biological markers (or biomarkers: Peters and Moldowan, 1993) and are useful in understanding more about source and maturity of organic matter in sediments. Biomarker assemblages in Site 859 sediments are unusually complex. This complexity is the result of the presence of both unsaturated hydrocarbons, indicating low thermal stress, and of saturated hydrocarbons with stereoconfigurations characteristic of mature organic matter.

In comparing biomarker data from sediment of the southern oceans, the results from the Cenozoic sediments at Site 859 contrast with the results from similar age sediments offshore of Antarctica (Kvenvolden, Rapp, et al., 1987; Kvenvolden et al., 1990; Kvenvolden et al., 1991). Most Cenozoic marine sediments near Antarctica contain reworked or recycled organic matter that leaves a mature signature on the biomarkers. By contrast, sediments at Site 859 are in part primary, containing immature, unsaturated biomarkers such as sterenes, fernenes, and hopenes, which have structures resembling their biologic precursors. Other southern ocean sediments with similar mixtures of immature, unsaturated biomarkers are the older Mesozoic sediments of the Weddell Sea (Kvenvolden et al., 1990) and the Falkland Plateau (Simoneit, 1980; von der Dick, Rullkötter, and Welte, 1983).

Sterenes are predominantly $\Delta^{2}$-isomers in Sample 141-859A-2H$3,60-66 \mathrm{~cm}$ ( $4.8 \mathrm{mbsf}$ ), the most shallow sample studied (see $\mathrm{m} / \mathrm{z} 215$ mass chromatogram in Fig. 4A). This unsaturation is consistent with an early diagenetic stage (Dastillung and Albrecht, 1977). In the $\mathrm{m} / \mathrm{z}$ mass chromatogram of two deeper samples (Fig. 4B and 4C) the progress in diagenesis is expressed by the presence of ster-4- and 

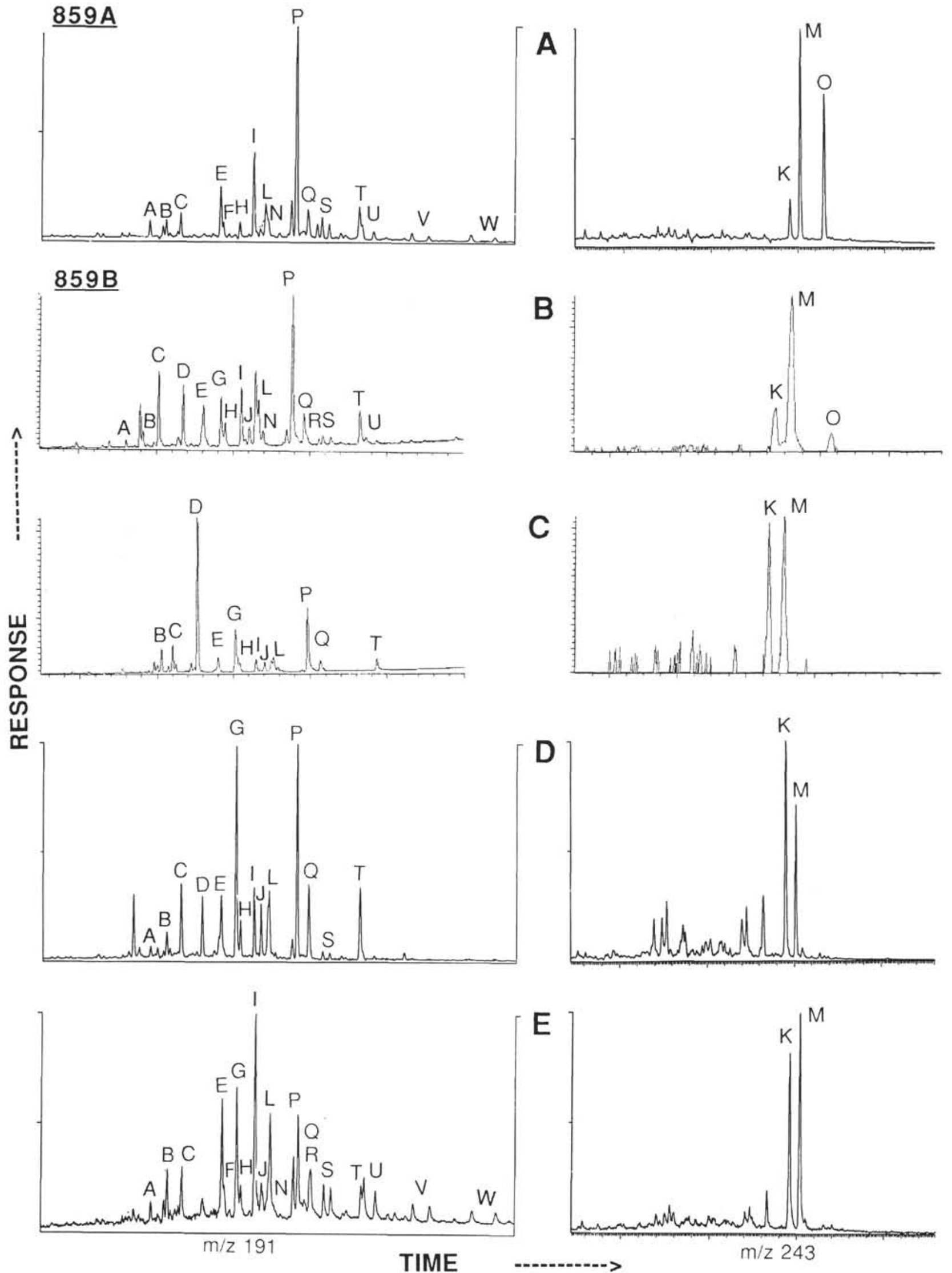

Figure 3. Typical mass chromatograms for terpenoid hydrocarbons ( $m / z$ 191 for hopenes, hopanes, and moretanes; $m / z 243$ for fernenes) for five selected sediment samples from Site 859. A. 141-859A-2H-3, 60-66 cm (4.8 mbsf). B. 141-859B-10R-2, 139-145 cm (198.4 mbsf). C. 141-859B-15R-1, 104-110 cm (246.1 mbsf). D. 141-859B-29R-3, 45-51 cm (382.9 mbsf). E. 141-859B-32R-1, 77-83 cm (409.4 mbsf). Compounds are identified in Table 2. Molecular ratios are given in Table 1. 


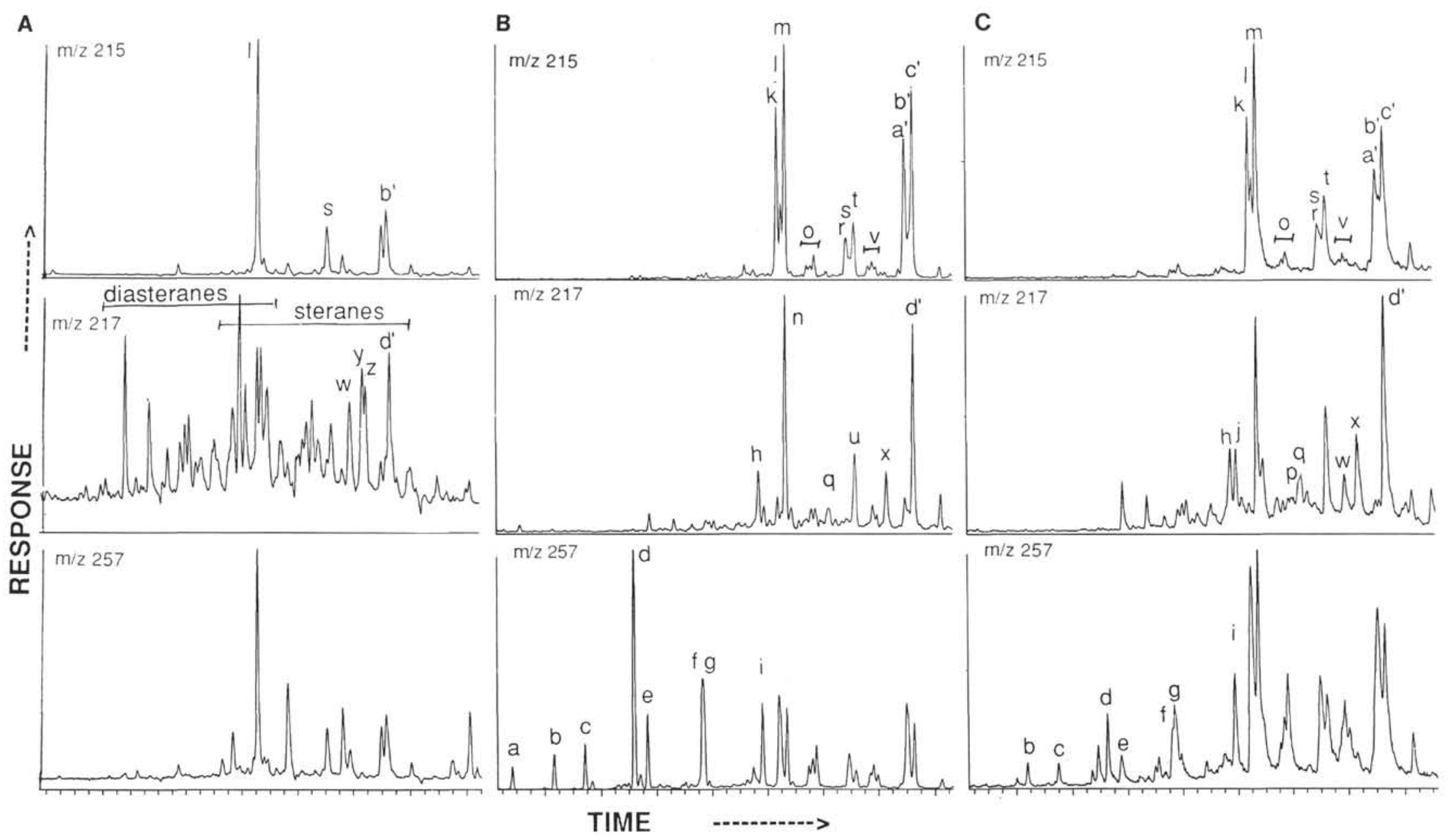

Figure 4. Typical mass chromatograms for steroid hydrocarbons $(\mathrm{m} / \mathrm{z} 215$ for sterenes, $\mathrm{m} / \mathrm{z} 217$ for steranes; $\mathrm{m} / \mathrm{z} 257$ for diasterenes and sterenes) for three sediment samples from Site 859 . A. 141-859A-2H-3, 60-66 cm (4.8 mbsf). B. 141-859B-29R-3, 45-51 cm (382.9 mbsf). C. 141-859B-32R-1, 77-83 cm (409.4 mbsf). Compounds are identified in Table 2. Molecular compound ratios are given in Table 1. 

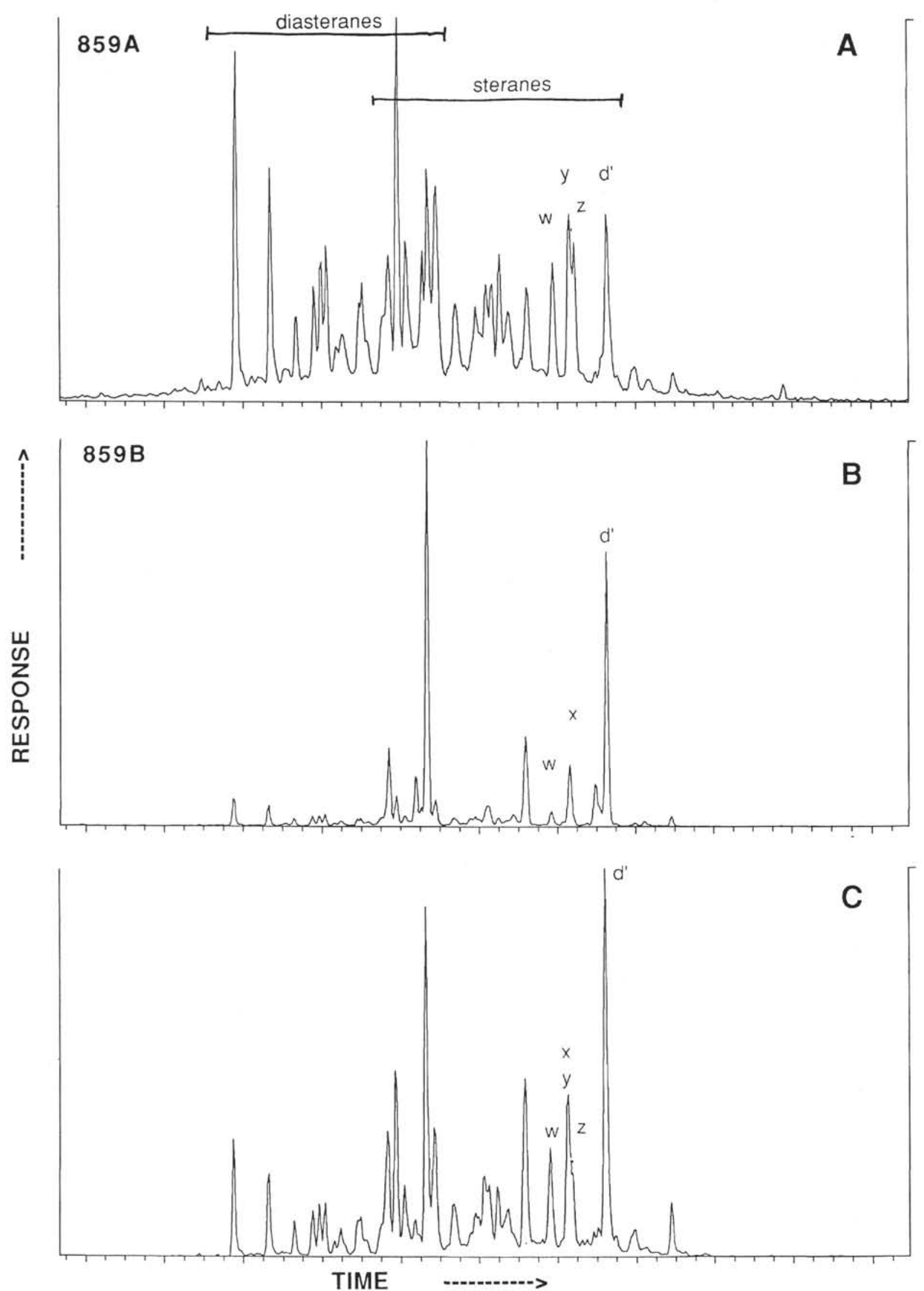

Figure 5. Molecular ion-to- $m / z 217$ transitions from linked scan experiments for three selected sediment samples from Site 859. A. 141-859A-2H-3, 60-66 cm (4.8 mbsf). B. 141-859B-29R-3, 45-51 cm (382.9 mbsf). C. 141-859B-32R-1, 77-83 cm (409.4 mbsf). Compounds are identified in Table 2. Molecular compound ratios are given in Table 1 . 
Table 2. Compound identification.

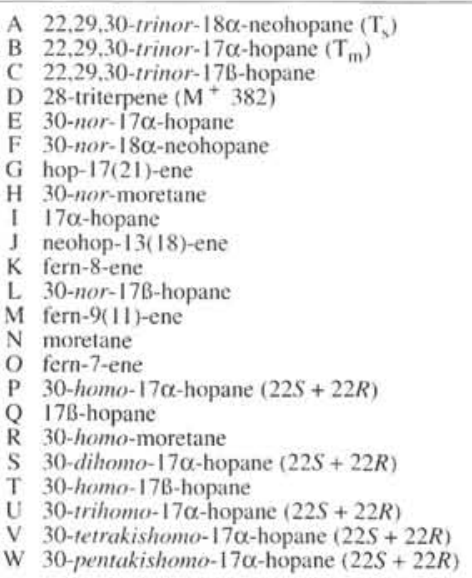

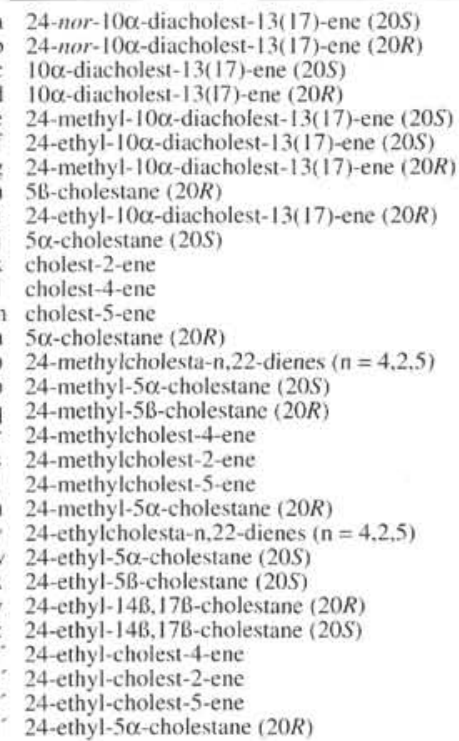

-5-enes, but even in the deepest sample, the $\Delta^{2}$-isomers are still present in appreciable amounts. The presence of these compounds indicates that thermal maturation has not significantly affected the primary organic matter in this sediment. In each case, the $\mathrm{C}_{27}$ pseudohomologs dominate, which is consistent with a marine origin for these steroid hydrocarbons.

Steradienes with an additional double bond at C-22 in the sidechain are present as another group of unsaturated steroid hydrocarbons in small concentrations as reported previously for other deep-sea sediments with immature organic matter (e.g., Rullkötter et al., 1984). The distribution of the A-ring double bond isomers of the steradienes parallels that of the sterenes. The $\mathrm{m} / \mathrm{z} 257$ mass chromatograms in Figure 4 essentially mirror the $m / z 215$ traces. Additional peaks with retention times shorter than those of the regular sterenes in the $m / z 257$ trace mostly represent diasterenes, whereas those peaks having larger retention times remain unidentified. Diasterenes occur only in the deeper samples studied (Fig. 4B and 4C); their presence results from the increasing level of diagenesis with depth (ten Haven et al., 1989).

Steranes are mainly $5 \beta$ - and $5 \alpha$-cholestanes and the corresponding 24-methyl and 24-ethyl pseudohomologs in Sample 141-859B$29 \mathrm{R}-3,45-51 \mathrm{~cm}$, from $382.9 \mathrm{mbsf}(\mathrm{m} / \mathrm{z} 217$ trace in Fig. 4B). The sterane distributions are more complex in Samples 141-859A-2H-3, $60-66 \mathrm{~cm}$ ( $4.8 \mathrm{mbsf}$ ), and 141-859B-32R-1, 77-83 cm (409.4 mbsf), apparently due to the presence of more mature organic matter in the bitumen fraction of these sediments $(\mathrm{m} / \mathrm{z} 217$; Fig. 4A and $4 \mathrm{C})$. This complexity can be more clearly inferred from the results of the linked scan experiments in Figure 5, which shows the sum of the $\mathrm{C}_{27}$ and $\mathrm{C}_{29}$ steranes without any interference from other bitumen constituents. The amount of more mature hydrocarbons admixed with the primary steranes is highest in Sample 141-859A-2H-3, 60-66 cm, followed by Sample 141-859B-32R-1, 77-83 cm (Fig. 5A and 5C), whereas in Sample 141-859B-29R-3, 45-51 cm, the primary $5 \beta$ - and $5 \alpha-(20 R)$ steranes clearly dominate (Fig. 5B). The molecular maturation epimer ratio of 24-ethyl cholestane $(20 S /[20 R+20 S])$ is often used in petroleum exploration (Mackenzie et al., 1980; Peters and Moldowan, 1993). Here this ratio measured 0.41 in the most shallow sample, a value as high as that in many mature Tertiary crude oils (Grantham, 1986). This sample has the largest admixture of mature organic matter. The values for the two older samples (Fig. 5B and 5C) are in the range of marginally mature and immature organic matter.

Fernenes ( $m / z 243$ mass chromatograms, Fig. 3 ) in Sample 141$859 \mathrm{~A}-2 \mathrm{H}-3,60-66 \mathrm{~cm}$ (4.8 mbsf) comprise all three isomers so far encountered in marine sediments. The least stable fern-7-ene (Ageta et al., 1987) represents a significant proportion of this isomer mixture, but this isomer has been completely converted to the more stable fern-8-ene and fern-9(11)-ene in the deeper samples (Fig. 3C-E). Among these two isomers, the increasing level of diagenesis is indicated by the higher relative concentration of the most stable isomer, fern-9(11)-ene, in the deepest sample. Because fernenes do not occur in mature organic matter fractions, their distributions in the Site 859 sediments have minimal interferences from other components.

Hopenes and hopanes occur in different relative amounts in the sediment samples from Site 859 , reflecting variable mixtures of immature primary and more mature allochthonous bitumen fractions. Hop-17(21)-ene is the dominant unsaturated triterpene and particularly prominent in Sample 141-859B-32R-1, 77-83 cm (409.9 mbsf; Fig. 3D). Where primary organic matter dominates in the hydrocarbon fraction, 30-homo-17 $\alpha$-hopane $(20 R)$ is the most abundant saturated hopanoid hydrocarbon (Fig. 3A-D). This compound represents a diagenetic conversion product of bacterial membrane constituents such as bacteriohopanetetrol (Ourisson et al., 1979) formed under oxic conditions (oxidative cleavage of side-chain followed by decarboxylation). In the same samples, $17 \beta$-hopanes with the steric configuration inherited from their biogenic precursors occur in significant amounts.

The hop-17(21)-ene/17 $\alpha$-hopane (hopene/hopane) ratio provides a measure of the relative importance of the immature organic matter fraction (Table 1), although slight changes (decrease of the ratio) caused by slight increasing levels of diagenesis with depth have to be taken into account. Evidence for the mixed nature of the bitumen of the samples in terms of thermal maturity is the carbon-number dependence of the C-22 epimer ratio of extended $17 \alpha$-hopanes (Table 1). This dependence is demonstrated in Figure 6, which shows the molecular ion-to- $m / z 191$ transitions for $C_{31}$ to $C_{35}$ extended $17 \alpha-$ hopanes for Sample 141-859A-2H-3, 60-66 cm (4.8 mbsf). For the $\mathrm{C}_{31}$ member the contribution of the immature fraction leads to a striking dominance of the epimer with the biogenic $22 R$ configuration. A minor contribution of the $22 R-\mathrm{C}_{32}$ pseudohomolog may also have occurred, but in general the $\mathrm{C}_{32}$ to $\mathrm{C}_{35}$ members of the series uniformly show an epimer ratio typical of mature organic matter of about 0.6 , the equilibrium value of the $22 S /(S+R)$ ratio (Mackenzie et al., 1980; Seifert and Moldowan, 1980; Mackenzie, 1984). Therefore, this ratio was calculated separately for the $\mathrm{C}_{31}$ and, as an average, the $C_{32}$ to $C_{35}$ extended $17 \alpha$-hopanes for Site 859 sediments 
(Table 1). The values of the latter ratio measure the maturity of the non-primary organic matter, whereas the former ratio addresses the relative contributions of both organic matter types. The values of the maturity parameter are largely uniform, which is not surprising because the epimer equilibrium is reached very early during organic matter maturation. The mixing parameter is variable, as are the other biological marker parameters sensitive to the mixing effect.

Two possible origins of the mature bitumen in the Site 859 sediments include the following: (1) The mature bitumen may have been incorporated as recycled material eroded from rocks with a geothermal history that has led to high maturity organic matter. (2) Alternatively, redistribution (migration) of mobile hydrocarbons within the sedimentary column off the coast of Chile may have caused the mixing effect. Organic petrographic investigations of these sediments (see Littke et al., this volume) have shown that the particulate organic matter consists mainly of inertinite. Inertinite represents either organic matter oxidized during transport from the continent or during settling in the water column or eroded material from rocks that have experienced higher thermal stress in the past. In any case, reflectance of these particles is so high that it does not correspond to the maturity level of the mature bitumen portion encountered at Site 859. Vitrinite is also present and is mainly primary; it has a low reflectance, and in terms of maturity corresponds more closely to the immature land-derived organic matter as indicated by the high-molecular-weight $n$-alkane mode with a strong predominance of molecules with odd-carbon numbers.

Although a contribution of recycled organic matter cannot be fully excluded, we favor migration of hydrocarbons from greater depth, possibly transported within a hydrothermal circulation system, as the main reason for the variable mixing of immature and mature components in the aliphatic (non-aromatic) fractions of the Site 859 sediments. Redistribution has not affected the entire sedimentary column homogeneously, resulting in variability of the mixing parameter values (Table 1).

Indigenous heating of the organic matter by hydrothermal fluids within the sedimentary column penetrated at Site 859 apparently has not occurred, as inferred from the presence of unsaturated hydrocarbons (e.g., ster-2-enes) in all samples studied. This observation is somewhat puzzling when account is taken of the present high geothermal gradient of about $100^{\circ} \mathrm{C} / \mathrm{km}$ and the finding of evidence for a hot fluid jet at 245 mbsf (Shipboard Scientific Party, 1992). A very hot $\left(\gg 61^{\circ} \mathrm{C}\right.$ ) and channelized influx of fluid appears to intersect the borehole near this depth. One might expect that such a stream of hot fluid acting over geologic time would have a profound effect on the sedimentary organic matter. However, Sample 141-859B-15R-1, 104-110 $\mathrm{cm}$, taken at $246.1 \mathrm{mbsf}$, does not appear to have been affected in any discernable manner. Distribution and maturity parameters listed in Table 1 indicate that this sample is similar to most of the overlying samples. The gas chromatogram of this sample (Fig. 2E) shows few interpretable differences compared to those of younger samples. Older samples do, however, show evidence of some advanced thermal diagenesis as discussed previously. We conclude that the postulated hot jet of fluid is likely an ephemeral event that has not been maintained in the past for sustained periods of time. Alternatively, the heating effect of the fluids may have extended only over a very short distance in these unconsolidated sediments, and the affected sediments were not sampled. The limited heating effects have been noted previously in studies of basalt intrusion into water-rich unconsolidated sediments where only the overlying and underlying one meter of sediment was thermally affected (Simoneit and Philp, 1982).

\section{CONCLUSIONS}

This organic geochemical survey at ODP Site 859, Leg 141, near the Chile Triple Junction suggests that the sediment organic matter, at least the high-molecular-weight hydrocarbons, are from both terrigenous and marine sources and have not been recycled, as is common in other southern ocean sediments, particularly those near Antarctica.

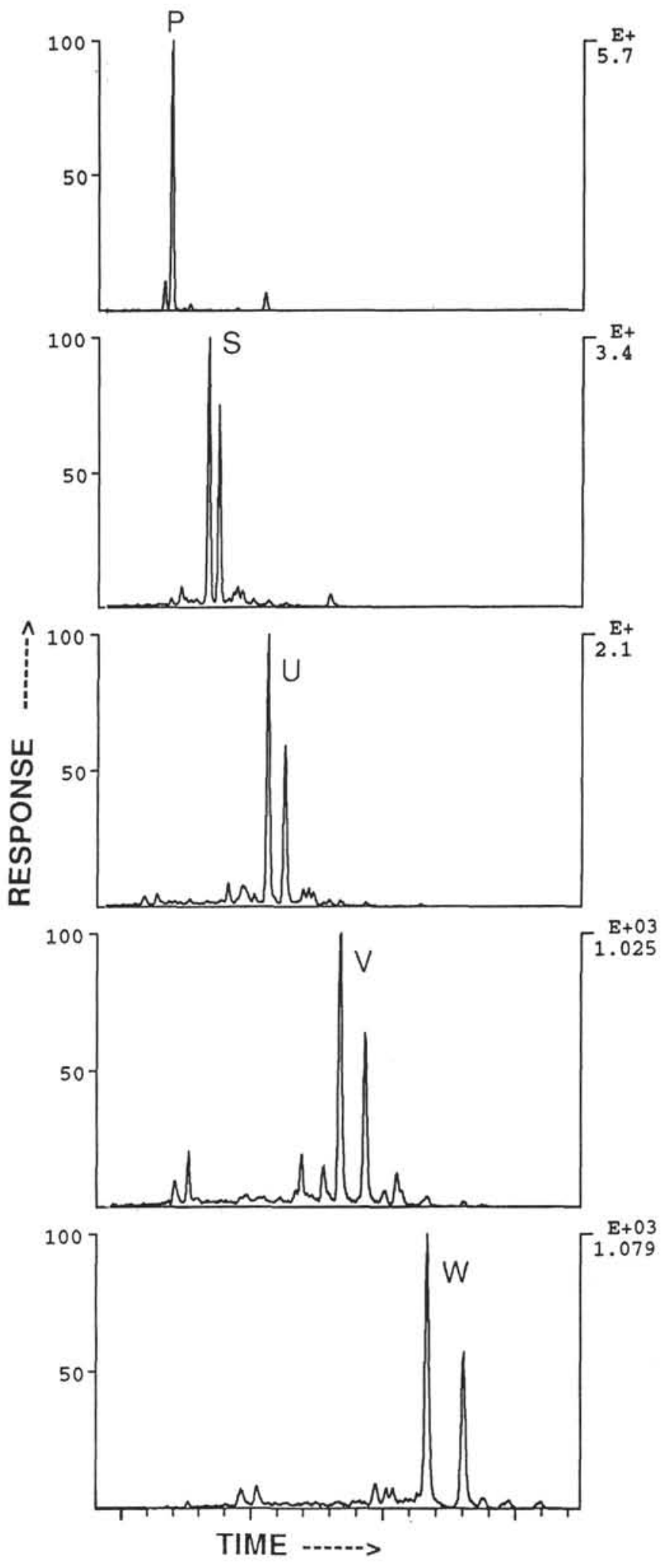

Figure 6. Molecular ion-to- $m / z 191$ transitions $\left(C_{31}\right.$ to $C_{35}$ extended $17 \alpha$ hopanes) from a linked scan experiment for Sample 141-859A-2H-3, 60-66 $\mathrm{cm}$ (4.8 mbsf) from Site 859. Compounds are identified in Table 2. Molecular compound ratios are given in Table 1 . 
The source of terrigenous plant material at Site 859 is likely from South America. Although the site, located at the toe of the slope near the Chile Trench and Ridge, has a high geothermal gradient $\left(100^{\circ} \mathrm{C} / \mathrm{km}\right)$ and a complex hot and cold fluid flow system, the sediment organic matter has undergone little change since its deposition. A hot jet of fluid $\left(>66^{\circ} \mathrm{C}\right.$ ) at $245 \mathrm{mbsf}$ has not had obvious effect on the hydrocarbon geochemistry, suggesting that the flow of hot fluids has not been sus- tained for very long periods of time or that the fluids were not hot enough to cause changes in a thick layer of sediment. Only toward the bottom of the borehole, between about 382 and 440 $\mathrm{mbsf}$, is there any organic geochemical evidence for a slight advance in thermal diagenesis. On the other hand, mature hydrocarbons found in various amounts as admixtures of the bitumen fractions of several sediment samples are interpreted to be material migrated from greater depth where the thermal influence of active continental processes had a stronger influence on the sedimentary organic matter. Circulating waters may have transported mature hydrocarbons into the shallow sediments sampled at Site 859.

\section{ACKNOWLEDGMENTS}

We thank the shipboard scientific and technical staff for their help in obtaining samples for geochemical analysis.

\section{REFERENCES*}

Ageta, H., Shiojima, K., and Arai, J., 1987. Acid-induced rearrangement of triterpenoid hydrocarbons belonging to the hopane and migrated hopane series. Chem. Pharm. Bull., 35:2705-2716.

Bangs, N., Cande, S.C., Lewis, S.D., and Miller, J., 1992. Structural framework of the Chile Margin at the Chile Ridge collision zone. In Behrmann, J.H., Lewis, S.D., Musgrave, R.J., et al., Proc. ODP, Init. Repts., 141: College Station, TX (Ocean Drilling Program), 11-21.

Brassell, S.C., Wardroper, A.M.K., Thomson, I.D., Maxwell, J.R., and Eglinton, G., 1981. Specific acyclic isoprenoids as biological markers of methanogenic bacteria in marine sediments. Nature, 290:693-696.

Brault, M., and Simoneit, B.R.T., 1988. Hydrothermally-enhanced diagenetic transformations. Org. Geochem., 13:697-705.

Clark, R.C., Jr., and Blumer, M., 1967. Distribution of $n$-paraffins in marine organisms and sediment. Limnol. Oceanogr., 12:79-87.

Cooper, J.E., and Bray, E.E., 1963. A postulated role of fatty acids in petroleum formation. Geochim. Cosmochim. Acta, 27:1113-1127.

Dastillung, M., and Albrecht, P., 1977. $\Delta^{2}$-sterenes as diagenetic intermediates. Nature, 269:678-679.

Didyk, B.M., Simoneit, B.R.T., Brassell, S.C., and Eglinton, G., 1978. Organic geochemical indicators of palaeoenvironmental conditions of sedimentation. Nature, 272:216-222.

Eglinton, G., Gonzales, A.G., Hamilton, R.J., and Raphael, R.A., 1962. Hydrocarbon constituents of the wax coatings of plant leaves: a taxonomic survey, Phytochemistry, 1:89-102.

Eittreim, S.L., Cooper, A.K., and Scientific Staff, 1984. Marine geological and geophysical investigations of the Antarctic continental margin, 1984. Geol. Surv. Circ. (U.S.), 935:1-12.

Grantham, P.J., 1986. Sterane isomerisation and moretane/hopane ratios in crude oils derived from Tertiary source rocks. Org. Geochem., 9:293-304.

Han, J., and Calvin, M., 1969. Hydrocarbon distribution of algae and bacteria and microbial activity in sediments. Proc. Nat. Acad. Sci. USA, 64:436-443.

Kvenvolden, K.A., Golan-Bac, M., and Rapp, J.B., 1987. Hydrocarbon geochemistry of sediments offshore from Antarctica: Wilkes Land continental margin. In Eittreim, S.L., and Hampton, M.A. (Eds.), The Antarctic Continental Margin: Geology and Geophysics of Offshore Wilkes Land. CircumPac. Counc. Energy Miner. Resour., Earth Sci. Ser., 5A:205-213.

Kvenvolden, K.A., Hostettler, F.D., and Frank, T.J., 1990. Hydrocarbons in sediment of the Weddell Sea, Antarctica. In Barker, P.F., Kennett, J.P., et al., Proc. ODP. Sci. Results, 113: College Station, TX (Ocean Drilling Program), 199-208.

Abbreviations for names of organizations and publications in ODP reference lists follow the style given in Chemical Abstracts Service Source Index (published by American Chemical Society).
Kvenvolden, K.A., Hostettler, F.D., Rapp, J.B., and Frank, T.J., 1991. Aliphatic hydrocarbons in sediments from Prydz Bay, Antarctica. In Barron, J., Larsen, B., et al., Proc. ODP, Sci. Results, 119: College Station, TX (Ocean Drilling Program), 417-424.

Kvenvolden, K.A., Rapp, J.B., Golan-Bac, M., and Hostettler, F.D., 1987. Multiple sources of alkanes in Quaternary oceanic sediment of Antarctica. Org. Geochem., 11:291-302.

Mackenzie, A.S., 1984. Applications of biological markers in petroleum geochemistry. In Brooks, J., and Welte, D.H. (Eds.), Advances in Petroleum Geochemistry (Vol. 1): London (Academic Press), 115-214.

Mackenzie, A.S., Patience, R.L., Maxwell, J.R., Vandenbroucke, M., and Durand, B., 1980. Molecular parameters of maturation in the Toarcian shales, Paris Basin, France-I. Changes in the configurations of acyclic isoprenoid alkanes, steranes and triterpanes. Geochim. Cosmochim. Acta, 44:1709-1722.

Mackie, P.R., Platt, H.M., and Hardy, R., 1978. Hydrocarbons in the marine environment, II. Distribution of $n$-alkanes in the fauna and environment of the sub-Antarctic island of South Georgia. Estuarine Coastal Mar. Sci., 6:301-313.

Matsumoto, G.I., Torii, T., and Hanya, T., 1979. Distribution of organic constituents in lake waters and sediments of the McMurdo Sound region in the Antarctic. Mem. Nat. Inst. Polar Res., Spec. Iss., 13:103-120.

McIver, R.D., 1975. Hydrocarbon gases in canned core samples from Leg 28 Sites 271, 272, and 273, Ross Sea. In Hayes, D.E., Frakes, L.A., et al., Init. Repts DSDP, 28: Washington (U.S. Govt. Printing Office), 815-817.

Ourisson, G., Albrecht, P., and Rohmer, M., 1979. The hopanoids: paleochemistry and biochemistry of a group of natural products. Pure Appl. Chem., 51:709-729.

Peters, K.E., and Moldowan, J.M., 1993. The Biomarker Guide: Englewood Cliffs, NJ (Prentice Hall).

Radke, M., Sittardt, H.G., and Welte, D.H., 1978. Removal of soluble organic matter from rock samples with a flow-through extraction cell. Anal. Chem., 50:663-665.

Radke, M., Willsch, H., and Welte, D.H., 1980. Preparative hydrocarbon group type determination by automated medium pressure liquid chromatography. Anal. Chem., 52:406-411.

Rapp, J.B., Kvenvolden, K.A., and Golan-Bac, M., 1987. Hydrocarbon geochemistry of sediment offshore from Antarctica. In Cooper, A.K., and Davey, F.J. (Eds.), The Antarctic Continental Margin, Geology and Geophysics of the Western Ross Sea. Circum-Pac. Counc. Energy Miner. Resour., Earth Sci. Ser., 5B:217-224.

Rullkötter, J., Mukhopadhyay, P.K., Schaefer, R.G., and Welte, D.H., 1984. Geochemistry and petrography of organic matter in sediments from Deep Sea Drilling Project Sites 545 and 547, Mazagan Escarpment. In Hinz, K., Winterer, E.L., et al., Init. Repts. DSDP, 79: Washington (U.S. Govt. Printing Office), 775-806.

Sackett, W.M., Poag, C.W., and Eadie, B.J., 1974. Kerogen recycling in the Ross Sea, Antarctica. Science, 185:1045-1047.

Seifert, W.K., and Moldowan, J.M., 1980. The effect of thermal stress on source-rock quality as measured by hopane stereochemistry. In Douglas, A.G., and Maxwell, J.R. (Eds.), Advances in Organic Geochemistry, 1979: Oxford (Pergamon Press), 229-237.

Shipboard Scientific Party, 1992. Site 859. In Behrmann, J.H., Lewis, S.D., Musgrave, R.J., et al., Proc. ODP, Init. Repts., 141: College Station, TX (Ocean Drilling Program), 75-157.

Simoneit, B.R.T., 1978. The organic chemistry of marine sediments. In Riley, J.P., and Chester, R. (Eds.), Chemical Oceanography (2nd ed.)(Vol. 7): New York (Academic Press), 233-311.

, 1980. Organic geochemistry of Mesozoic sediments from Deep Sea Drilling Project Site 330, Falkland Plateau. In Lancelot, Y., Winterer, E.L., et al., Init. Repts. DSDP, 50: Washington (U.S. Govt. Printing Office), $637-641$.

Simoneit, B.R.T., and Philp, R.P., 1982. Organic geochemistry of lipids and kerogen and the effects of basalt intrusions on unconsolidated oceanic sediments: Sites 477, 478, and 481, Guaymas Basin, Gulf of California. In Curray, J.R., Moore, D.G., et al., Init. Repts. DSDP, 64 (Pt. 2): Washington (U.S. Govt. Printing Office), 883-904.

ten Haven, H.L., de Leeuw, J.W., Rullkötter, J., and Sinninghe Damste, J.S., 1987. Restricted utility of the pristane/phytane ratio as a paleoenvironmental indicator. Nature, 330:641-643.

ten Haven, H.L., Rullkötter, J., and Welte, D.H., 1989. Steroid biological marker hydrocarbons as indicators of organic matter diagenesis in deep sea sediments: geochemical reactions and influence of different heat flow regimes. Geol. Rundsch., 78:841-850. 
Venkatesan, M.I., 1988. Organic geochemistry of marine sediments in Antarctic region: marine lipids in McMurdo Sound. Org. Geochem., 12:13-27. Venkatesan, M.I., and Kaplan, I.R., 1987. The lipid geochemistry of Antarctic marine sediments: Bransfield Strait. Mar: Chem., 21:347-375.

von der Dick, H., Rullkötter, J., and Welte, D.H., 1983. Content, type and thermal evolution of organic matter in sediments from the eastern Falkland Plateau, Deep Sea Drilling Project, Leg 71. In Ludwig, W.J., Krasheninnikov, V.A., et al., Init. Repts. DSDP, 71 (Pt. 2): Washington (U.S. Govt. Printing Office), 1015-1032.
Whiticar, M.J., Suess, E., and Wehner, H., 1985. Thermogenic hydrocarbons in surface sediments of the Bransfield Strait, Antarctic Peninsula. Nature, 314:87-90.

Date of initial receipt: 23 August 1993

Date of acceptance: 3 May 1994

Ms 141SR-020 